\title{
Faktor yang Behubungan dengan Stigma Masyarakat terhadap Pasien Post-COVID
}

\author{
Retno Widiarini ${ }^{1}$, Intan Okrima Putri ${ }^{2 *}$, Suhadi Prayitno ${ }^{3}$ \\ ${ }^{1-3}$ Program Studi Kesehatan Masyarakat, STIKES Bhakti Husada Mulia Madiun
}

\begin{abstract}
Abstrak
Stigma merupakan tindakan negatif yang dapat menurunkan kepercaya dirian seseorang. Pada masa pandemi COVID19 stigma ini dapat berupa penolakan jenazah, pengusiran petugas kesehatan ataupun pengucilan terhadap keluarga pasien yang terkonfirmasi COVID-19 maupun pasien post-COVID. Penelitian ini bertujuan untuk mencari tahu faktor apa saja yang berhubungan dengan stigma yang ada di masyarakat terhadap pasien post-COVID di Dusun Papringan Desa Sidomukti Kec. Plaosan Kab. Magetan. Jenis penelitian yaitu kuantitatif dengan jenis Cross Sectional. Populasi dalam penelitian ini yaitu masyarakat yang bertempat tinggal di Dusun Papringan berusia 26-45 tahun dengan sampel menggunakan rumus slovin yaitu sebanyak 97 responden. Teknik sampling yang digunakan yaitu Purposive Sampling dengan kuesioner dan observasi. Analisis data penelitian menggunakan uji Chi-Square. Hasil penelitian didapatkan hubungan antara pengetahuan $(P v=0,000 ; P R=2,332)$, sikap $(P v=0,000 ; P R=2,28 I)$, fungsi pelayanan kesehatan dalam memberikan penyuluhan $(\mathrm{Pv}=0,006, P R=1,636)$, peran tokoh masyarakat $(\mathrm{Pv}=0,000 ; P R=2,235)$ dengan stigma masyarakat terhadap pasien post-COVID di Dusun Papringan Desa Sidomukti Kec. Plaosan Kab. Magetan. Dari penelitian ini, saran yang disampaikan adalah agar penelitian ini dapat digunakan sebagai referensi peneliti selanjutnya untuk lebih mengembangkan isi dari penelitian ini.
\end{abstract}

Kata Kunci: Stigma, pasien post-COVID, pengetahuan, sikap, pelayanan kesehatan.

\begin{abstract}
Stigma is a negative action that can reduce a person's self-confidence. During the COVID-19 pandemic, this stigma can be in the form of refusal of bodies, expulsion of medical staff or excommunication of patients with confirmed COVID-19 and postCOVID patients. This study aims to find out what factors are related to community stigma against post-COVID patients in Papringan Hamlet, Sidomukti Village, District of Plaosan and Magetan regency. This type of quantitative research with cross sectional type. The population of this research is the people who live in Papringan Hamlet, aged 26-45 years with a sample using the slovin formula, which is 97 respondents. The sampling technique used purposive sampling with questionnaires and observations. Data analysis used the chi-square test. The results of the study showed a relationship between knowledge $(P v=0,000 ; P R=2,332)$, attitude $(P v=0,000 ; P R=2,28 I)$, health service function in providing counseling $(P v=0,006$; $P R=I, 636)$, the role of community leaders $(P v=0,000 ; P R=2,235)$ with community stigma against post-COVID patients in Papringan Hamlet, Sidomukti Village, Plaosan District, Magetan Regency. From this research, the suggestion given is that this research can be used as a reference for further researchers to further develop this research.
\end{abstract}

Keywords : Stigma, post-COVID patients, knowledge, attitude, health service.

Korespondensi*: Intan Okrima Putri, Program Studi Kesehatan Masyarakat, Sekolah Tinggi llmu Kesehatan Bhakti Husada Mulia Madiun, Jl. Taman Praja No.25, Mojorejo, Kec. Taman, Kota Madiun, Jawa Timur 63/39, E-mail: okrimaintan99@gmail.com, No.Telp: +6281239490935 


\section{Pendahuluan}

Pada tahun 2020, dunia dikejutkan dengan adanya penyakit yang belum diketahui penyebabnya. Penyakit tersebut dilaporkan pertama kali oleh China kepada World Health Organization (WHO) yang mengatakan terdapat 44 pasien menderita pneumonia berat di Kota Wuhan, Provinsi Hubei, China yang terjadi diakhir tahun 2019. Diduga penyakit ini berawal dari pasar basah yang menjual berbagai jenis ikan, hewan laut dan hewan lain. Pada tanggal 10 Januari 2020 mulai ditemukannya penyebab penyakit ini dengan kode genetik yaitu virus corona baru. ${ }^{1}$ Virus ini kemudia disebut sebagai sindrom pernapasan akut parah coronavirus 2 (SARS-CoV-2) dan dapat menular dengan sangat cepat dari manusia satu ke manusia lainnya melalui interaksi yang terjadi secara langsung. ${ }^{2}$

Berdasarkan data yang dikeluarkan oleh WHO secara global pada tanggal 22 Februari 2021, dinyatakan sebanyak 110.974.862 orang terkonfirmasi positif virus COVID-19 dengan angka kematian mencapai 2.460.792 kasus. Di Indonesia didapatkan pertama kalinya 2 kasus pasien yang terkonfirmasi COVID-19 pada tanggal 2 Maret 2020. Hingga saat ini, sampai tanggal 22 Februari 2021 tercatat sebanyak 1.278.653 orang yang terkonfirmasi positif dengan 34.489 orang kasus kematian. Peningkatan angka kasus virus COVID-19 terus terjadi setiap harinya, bahkan Indonesia mengalami peningkatan harian tertinggi yaitu pada tanggal 30 Januari 2021 yaitu sebanyak 14.518 orang yang terkonfirmasi positif.

Kabupaten Magetan merupakan salah satu wilayah yang berada di Provinsi Jawa Timur. Wilayah tersebut juga terpapar virus COVID-19. Pada tanggal 23 Februari 2021, dilaporkan sebanyak 2.337 orang yang terkonfirmasi virus COVID-19 dengan angka kematian 186 orang. Desa Sidomukti, merupakan salah satu desa yang berada di Kabupaten Magetan yang tercatat adanya penderita yang telah sembuh dari virus COVID-19. Sebanyak 2 orang pasien COVID-19 yang dinyatakan sembuh pada bulan Agustus 2020 dan tidak terjadi peningkatan jumlah penderita virus COVID-19 pada desa tersebut. ${ }^{3}$

Peningkatan jumlah kasus yang terkonfirmasi virus COVID-19 sangat berpengaruh terhadap kecemasan seluruh masyarakat, tidak hanya wilayah yang terpapar virus COVID-19 tetapi juga wilayah yang belum pernah terpapar. Hal ini dapat menimbulkan berbagai stigma negatif kepada penderita, seseorang yang beresiko tinggi tertular virus COVID-19 seperti dokter, perawat, tenaga kesehatan maupun masyarakat yang berasal dari luar daerah yang beresiko menularkan virus COVID-19. Berdasarkan hasil observasi yang telah dilakukan peneliti sebelumnya pada bulan Oktober 2020, stigma negatif yang terjadi di Dusun Papringan yaitu seperti penolakan jenazah yang positif terpapar virus COVID-19, pengusiran petugas kesehatan dan pengucilan keluarga pasien yang terkonfirmasi virus COVID-19 maupun yang telah sembuh dari virus COVID-19. Stigma negatif yang dilakukan oleh masyarakat dapat menurunkan kepercayaan diri penderita dalam berinteraksi dengan orang lain serta membatasi akses untuk pergi ke pelayanan kesehatan, sehingga penderita yang mengalami gejala tidak ingin memeriksakan diri. ${ }^{4}$

Oleh sebab itu, berdasarkan latar belakang di atas masalah yang diangkat dalam penelitian ini adalah stigma masyarakat yang terjadi dikarenakan adanya penolakan masyarakat terhadap pasien Post-COVID di Desa Sidomukti Kec. Plaosan Kab. Magetan sehingga penelitian ini bertujuan untuk mengetahui faktor apa saja yang berhubungan dengan stigma masyarakat terhadap pasien PostCOVID.

\section{Metode}

Metode yang digunakan dalam penelitian ini yaitu survei analitik. Penelitian analitik memiliki tujuan untuk mencari hubungan antar variabel dari suatu 
fenomena. Desain penelitian yang digunakan dalam penelitian ini adalah penelitian kuantitatif dengan desain studi cross sectional.

Populasi dalam penelitian ini yaitu masyarakat yang tinggal di Dusun Papringan Desa Sidomukti yang diwilayahnya tercatat memiliki pasien Post-COVID dengan kategori usia dewasa awal dan dewasa akhir (26-45 tahun) dikarenakan pada masa ini seseorang belum mengalami penurunan pada kemampuan komunikasi sehingga tidak menghambat peneliti pada saat melakukan penelitian dan mengambil data. Jumlah populasi berdasarkan kategori usia yang telah ditentukan didapatkan sebanyak 129 orang. Dari perhitungan rumus slovin, didapatkan sampel sebanyak 97 orang. Sampel dalam penelitian ini adalah sebagian masyarakat yang tinggal di Dusun Papringan Desa Sidomukti Kec. Plaosan
Kab. Magetan dengan kriteria yang telah ditetapkan sebagai sampel oleh peneliti.

Dalam penelitian ini, peneliti menggunakan instrumen penelitian berupa kuesioner yang berjumlah sebanyak 36 soal dengan teknik pengambilan sampel menggunakan nonprobability sampling dengan jenis purposive sampling. Jenis data yang digunakan yaitu data primer yang merupakan jawaban dari hasil penyebaran kuesioner dan data sekunder berupa jumlah penduduk berdasarkan usia serta data pasien Post-COVID di Dusun Papringan yang didapatkan dari pihak lain seperti Bidan dan Perawat Desa Sidomukti, Petugas Kantor Desa Sidomukti, Puskesmas Sumberagung serta jurnal penelitian lain. Penggolahan data menggunakan distribusi frekuensi dan analisis data secara univariat dan bivariat dengan uji Chi-Square dengan nilai signifikasi sebesar 0,05.

\section{Hasil}

Tabel 1. Analisis Univariat

\begin{tabular}{llcc}
\hline \multicolumn{1}{c}{ Variabel } & \multicolumn{1}{c}{ Kategori } & n & \% \\
\hline Usia & 26-35 tahun & 36 & 37 \\
\multirow{3}{*}{ Jenis Kelamin } & 36-45 tahun & 61 & 63 \\
\multirow{3}{*}{ Pekerjaan } & Laki-laki & 18 & 18,6 \\
& Perempuan & 79 & 81,4 \\
& Pegawai Negeri/TNI.POLRI & 2 & 2,1 \\
& Pegawai Swasta & 14 & 14,4 \\
& Wiraswasta & 20 & 20,6 \\
& Petani & 10 & 10,3 \\
& Buruh & 10 & 10,3 \\
& Ibu Rumah Tangga & 36 & 37,1 \\
& Tidak Bekerja & 5 & 5,2 \\
Pendidikan Terakhir & Tamat Pendidikan Dasar & 35 & 36,1 \\
& Tamat Pedidikan Menengah & 46 & 47,4 \\
& Tamat Pendidikan Tinggi & 16 & 16,5 \\
\hline
\end{tabular}

Berdasarkan tabel 1 sebagian besar responden memiliki usia 36-45 tahun yaitu sebanyak 61 responden (63\%). Berdasarkan jenis kelamin sebagian besar responden berjenis kelamin perempuan yaitu sebanyak 79 responden $(81,4 \%)$. Berdasarkan pekerjaan sebagian besar responden memiliki pekerjaan sebagai ibu rumah tangga sebanyak 36 responden $(37,1 \%)$ dan berdasarkan pendidikan terakhir sebagian besar responden tamat pendidikan menengah sebanyak 46 responden $(47,4 \%)$.

Berdasarkan hasil analisa hubungan pengetahuan dengan stigma pasien PostCOVID didapatkan nilai $\mathrm{Pv}=0,000<\alpha$ $(0,05)$, sehingga dapat diambil kesimpulan bahwa terdapat hubungan pengetahuan dengan stigma pasien Post-COVID dengan nilai $P R \quad 95 \% \quad C I=2,332(1,736-3,133)$ yang berarti bahwa orang dengan pengetahuan yang buruk berpotensi 2,332 
Tabel 2. Analisis Bivariat

\begin{tabular}{|c|c|c|c|c|c|c|c|}
\hline \multirow{3}{*}{ Variabel } & \multirow{3}{*}{ Kategori } & \multicolumn{4}{|c|}{$\begin{array}{c}\text { Stigma Pasien Post- } \\
\text { COVID }\end{array}$} & \multirow{3}{*}{ Pvalue } & \multirow{3}{*}{$\begin{array}{c}P R \\
95 \% C I\end{array}$} \\
\hline & & \multicolumn{2}{|c|}{ Ya } & \multicolumn{2}{|c|}{ Tidak } & & \\
\hline & & $\mathbf{n}$ & $\%$ & $\mathbf{n}$ & $\%$ & & \\
\hline \multirow[t]{2}{*}{ Pengetahuan } & Kurang baik & 31 & 32 & 1 & 1 & \multirow{2}{*}{0,000} & 2,332 \\
\hline & Baik & 27 & 28 & 38 & 39 & & $(1,736-3,133)$ \\
\hline \multirow[t]{2}{*}{ Sikap } & Negatif & 32 & 33 & 2 & 2 & \multirow{2}{*}{0,000} & 2,281 \\
\hline & Positif & 26 & 27 & 37 & 38 & & $(1,679-3,098)$ \\
\hline \multirow{2}{*}{$\begin{array}{l}\text { Fungsi pelayanan kesehatan } \\
\text { dalam memberikan penyuluhan }\end{array}$} & Kurang baik & 31 & 32 & 9 & 9 & \multirow{2}{*}{0,006} & 1,636 \\
\hline & Baik & 27 & 28 & 30 & 31 & & $(1,187-2,254)$ \\
\hline \multirow[t]{2}{*}{ Peran tokoh masyarakat } & Tidak berpengaruh & 36 & 37 & 5 & 5 & \multirow{2}{*}{0,000} & 2,235 \\
\hline & Berpengaruh & 22 & 23 & 34 & 35 & & $(1,583-3,156)$ \\
\hline
\end{tabular}

kali lebih besar memiliki stigma pasien Post-COVID dibandingkan dengan orang yang memiliki pengetahuan baik.

Berdasarkan hasil analisa hubungan sikap dengan stigma pasien Post-COVID didapatkan nilai $\mathrm{Pv}=0,000<\alpha \quad(0,05)$, sehingga dapat diambil kesimpulan bahwa terdapat hubungan sikap dengan stigma pasien Post-COVID dengan nilai PR 95\% $\mathrm{CI}=2,281 \quad(1,679-3,098)$ yang berarti bahwa orang dengan sikap negatif berpotensi 2,281 kali lebih besar memiliki stigma pasien Post-COVID dibandingkan dengan orang yang memiliki sikap positif.

Berdasarkan hasil analisa hubungan fungsi pelayanan kesehatan dalam memberikan penyuluhan dengan stigma pasien Post-COVID didapatkan nilai $\mathrm{Pv}=0,006<\alpha(0,05)$ sehingga dapat diambil kesimpulan bahwa terdapat hubungan fungsi pelayanan kesehatan dalam memberikan penyuluhan dengan stigma pasien Post-COVID dengan nilai PR 95\% $\mathrm{CI}=1,636(1,187-2,254)$ yang berarti bahwa orang yang menilai fungsi pelayanan kesehatan dalam memberikan penyuluhan buruk berpotensi 1,636 kali lebih besar memiliki stigma pasien PostCOVID dibandingan dengan orang yang menilai fungsi pelayanan kesehatan dalam memberikan penyuluhan baik.

Berdasarkan hasil analisa hubungan peran tokoh masyarakat dengan stigma pasien Post-COVID didapatkan nilai $\mathrm{Pv}=0,000<\alpha \quad(0,05)$, sehingga dapat diambil kesimpulan bahwa terdapat hubungan peran tokoh masyarakat dengan stigma pasien Post-COVID dengan nilai $P R$ 95\% CI $=2,235(1,583-3,158)$ yang berarti bahwa orang dengan penilaian peran tokoh masyarakat tidak berpengaruh berpotensi 2,235 kali lebih besar memiliki stigma pasien Post-COVID dibandingkan dengan orang yang memberikan penilaian peran tokoh masyarakat berpengaruh.

\section{Pembahasan}

Berdasarkan hasil penelitian yang telah dilakukan di Dusun Papringan, pengetahuan berguna sebagai dasar dari seseorang untuk melakukan suatu tindakan. Masyarakat yang memiliki pengetahuan yang kurang baik lebih banyak memiliki stigma negatif terhadap pasien PostCOVID. Masih banyak masyarakat yang menganggap virus ini merupakan virus berbahaya yang dapat mengakibatkan kematian, sehingga mereka memiliki rasa ketakutan yang berlebih jika berinteraksi dengan orang yang terkonfirmasi virus COVID-19 maupun orang yang telah sembuh dari virus COVID-19. Namun tidak sedikit masyarakat yang memiliki pengetahuan baik juga memiliki stigma pasien Post-COVID. Hal ini disebabkan karena orang tersebut ingin melindungi diri sendiri dan keluarganya, sehingga bertindak secara berlebihan seperti tidak memperbolehkan salah satu dari anggota keluarganya untuk berinteraksi secara langsung dengan pasien Post-COVID.

Hasil penelitian ini diperkuat dengan hasil penelitian sebelumnya yang menyatakan bahwa pengetahuan memiliki 
hubungan dengan stigma ODHA, dari ketidakpahaman masyarakat mengenai cara penularan HIV dapat menimbulkan stigma negatif terhadap orang yang menderita HIV. Apabila pengetahuan dari seseorang baik, maka dapat mendorong sikap seseorang untuk tidak melakukan stigma negatif. ${ }^{5,6}$ Begitu pula sebaliknya, apabila pengetahuan dari seseorang kurang baik akan mendorong sikap seseorang untuk melakukan stigma negatif. Selain itu, hal ini juga diperkuat oleh penelitian lain yang menyatakan bahwa kurangnya pengetahuan seseorang dapat membuat kesalah pahaman dan munculnya rasa ketakutan yang berlebih, hal ini merupakan salah satu faktor yang dapat menimbulkan stigma negatif. ${ }^{7}$

Berdasarkan hasil penelitian yang telah dilakukan di Dusun Papringan terdapat banyak masyarakat yang memiliki sikap negatif sehingga menyebabkan adanya stigma terhadap pasien PostCOVID. Tidak sedikit masyarakat yang merasa takut dan malu dengan keberadaan pasien Post-COVID. Hal ini merupakan salah satu faktor penyebab adanya stigma pasien Post-COVID. Hal ini didukung dengan penelitian lain yang menyatakan bahwa sikap terhadap stigma yang paling banyak terjadi yaitu sikap yang berhubungan dengan pemberian nama terhadap seseorang yang dianggap berbeda atau yang memiliki nilai negatif, sikap negatif ini disebut juga stigma "labelling". 8,9 Hasil ini diperkuat dengan hasil penelitian sebelumnya yaitu sikap negatif merupakan hal yang harus dihindari, karena menyebabkan orang lain sulit untuk menyembuhkan dirinya sendiri dan bangkit dari kegagalan, tidak memiliki kebebasan yang sama dengan kebanyakan masyarakat lainnya dan dapat menyebabkan keluarga merasa malu dan terganggu. ${ }^{10}$ Sikap juga merupakan salah satu penyebab yang dapat mengakibatkan stigma. Dalam hal ini, sikap yang ditujukkan lebih ke arah negatif seperti memperlihatkan adanya penolakan ataupun pengucilan terhadap orang yang dianggap berbeda dengan orang lainnya. ${ }^{11}$

Penelitian membuktikan adanya hubungan fungsi pelayanan kesehatan dalam memberikan penyuluhan dengan stigma pasien Post-COVID di Dusun Papringan. Hal ini diperkuat dengan hasil penelitian sebelumnya bahwa penyuluhan kesehatan merupakan suatu bagian dari pelayanan kesehatan yang bertujuan untuk meningkatkan pengetahuan masyarakat dan menanamkan keyakinan sehingga masyarakat tidak hanya sadar, tahu dan mengerti melainkan masyarakat juga melakukan tindakan sesuai dengan apa yang telah dianjurkan terhadap kesehatan. ${ }^{12}$ Hal ini juga sejalan dengan penelitian lain bahwa penyuluhan memiliki hubungan dengan stigma negatif terhadap penderita HIV/AIDS, Dimana terjadi penurunan tingkat stigma sebelum dilakukan penyuluhan dengan sesudah dilakukan penyuluhan. ${ }^{13}$

Hasil analisa bivariat penelitian ini didapatkan hubungan peran tokoh masyarakat dengan stigma pasien PostCOVID di Dusun Papringan. Hal ini diperkuat dengan hasil penelitian lain yang menyatakan bahwa keberadaan tokoh masyarakat memiliki peran yang sangat penting dalam membantu menurunkan presepsi dan stigma negatif yang ada karena tokoh masyarakat memiliki pengaruh dan dihormati dilingkungan. Rasa hormat yang diberikan bisa karena kekayaan, pengetahuan ataupun kesuksesan dalam memimpin masyarakat. ${ }^{14}$ Tokoh masyarakat memiliki fungsi yang bermacam-macam, tergantung dengan bidang masing-masing yang dimiliki. Orang yang menjadi tokoh masyarakat merupakan orang yang memiliki bakat, berwawasan luas serta memiliki semangat untuk mengajak masyarakat lainnya membangun suatu wilayah ke arah yang lebih baik lagi. ${ }^{15}$ Kebanyakan masyarakat di Dusun Papringan memberikan penilaian peran tokoh masyarakat tidak berpengaruh dikarenakan belum adanya contoh perilaku 
yang diberikan oleh tokoh masyarakat dalam mencegah peningkatan virus COVID-19 dan mencegah adanya stigma pasien Post-COVID seperti tidak menggunakan masker saat keluar rumah dan saat berinteraksi dengan masyarakat lainnya, tidak memberikan teguran terhadap masyarakat yang melanggar protokol kesehatan serta tidak adanya sanksi yang diberikan kepada masyarakat yang telah melanggar aturan yang telah ditetapkan. Hal ini mengakibatkan masyarakat ikut tidak mematuhi protokol kesehatan dan terjadi peningkatan jumlah penderita virus COVID-19.

\section{Kesimpulan}

Dari hasil penelitian ini disimpulkan bahwa faktor pengetahuan, sikap, fungsi pelayanan kesehatan dalam memberikan penyuluhan dan peran tokoh masyarakat memiliki hubungan dengan stigma pasien Post-COVID. Diharapkan dengan adanya penelitian ini dapat meminimalisir adanya stigma pasien Post-COVID dengan cara meningkatkan pengetahuan, fungsi pelayanan kesehatan dalam memberikan penyuluhan serta peran tokoh masyarakat yang dapat mempengaruhi sikap seseorang untuk tidak melakukan stigma negatif terhadap pasien Post-COVID baik di Dusun Papringan ataupun di wilayah lain. Pada peneliti selanjutnya, diharpkan dapat mengembangkan penelitian ini dengan mencari tahu lebih banyak faktor apa saja yang berhubungan dengan stigma pasien Post-COVID.

\section{Daftar Pustaka}

1. Setiawati L, Sariti I, Livana P. Stigma dan perilaku masyarakat pada pasien positif covid19. J Gawat Darurat. 2020;2(2):95-100.

2. Fadli F, Safruddin S, Ahmad AS, Sumbara S, Baharuddin R. Faktor yang mempengaruhi kecemasan pada tenaga kesehatan dalam upaya pencegahan COVID-19. J Pendidik Keperawatan Indones. 2020;6(1):57-65.

3. Dinas Kesehatan Kabupaten Magetan.
COVID-19 [Internet]. 2020. Available from: https://covid19.magetan.go.id/

4. Ardani I, Handayani S. Stigma terhadap Orang dengan HIV/AIDS (ODHA) sebagai hambatan pencarian pengobatan: studi kasus pada pecandu narkoba suntik di Jakarta. Bul Penelit Kesehat. 2017;45(2):81-8.

5. Saprudin A, Heriana C, Jatiningsih S. Pengetahuan dan sikap stigma mahasiswa kebidanan STIKES Kuningan Terhadap Orang Dengan HIV/AIDS (ODHA). J Ilmu-ilmu Kesehat Bhakti Husada Kuningan. 2015;4(2):22-5.

6. Maharani F. Faktor -Faktor yang berhubungan dengan stigma terhadap orang dengan HIV dan AIDS (Odha). J Endur. 2017;2(2):158.

7. Puspita A, Hayati F, Fuadah DZ. Stigma masyarakat terhadap Orang Dengan Hiv Aids (Odha). J Ilmu Kesehat. 2017;8(2):151-9.

8. Jufrizal dan Nurhasanah. Stigma masyarakat pada penderita kusta. Idea Nurs J. 2019;10(1):27-31.

9. Martiningsih, Abdul H, Ade W. Stigma Petugas Kesehatan Terhadap Pasien Hiv/Aids Dan Problem Solving. J Kesehat Prima. 2015;I(2):1471-7.

10. Garamina HJ. Hubungan pengetahuan dan sikap masyarakat terhadap stigma penyakit. J Aromed Unila. 2015;2(3):326-32.

11. Nirindah R, Prastiwi W, Studi P, Masyarakat K, Kesehatan FI, Surakarta UM. Hubungan pengetahuan, sikap dan persepsi anggota WPA Tentang HIV/ AIDS dengan Stigma Pada ODHA di Surakarta. 2019; hal 1,5,7.

12. Wulandari ISM, Namah I. Penyuluhan kesehatan tentang hiv/aids terhadap pengetahuan dan sikap pada siswa SMA Negeri Parongpong Desa Cihanjuang Kecamatan Bandung Barat. J Sk Keperawatan. 2019;5(1):56-62.

13. Latifa A, Purwaningsih SS. Peran masyarakat madani dalam mengurangi stigma dan diskriminasi terhadap penderita HIV \&amp; AIDS. J Kependud Indones. 2016;6(2):51-76.

14. Rembang, Prisilia. Lasut, J. Kandowangko N. Peranan tokoh masyarakat dalam penanganan masalah sengketa tanah di Desa Sulu Kecamatan Tatapaan Kabupaten Minahasa Selatan. 2018;(21).

15. Yani F, Harahap FSD, Hadi AJ. Stigma masyarakat terhadap Orang Dengan HIV/AIDS (ODHA) Di Kabupaten Aceh Utara. MPPKI (Media Publikasi Promosi Kesehatan Indonesia J Heal Promot. 2020;3(1):56-62. 